\title{
SUFFERING IN CHRIS GARDNER'S AUTOBIOGRAPHY THE PURSUIT OF HAPPYNESS
}

\author{
Elsa Violita and Devi Pratiwy \\ Graduate Program, Faculty of literature, Universitas Islam Sumatera Utara, Medan \\ e-mail: elsviolita@gmail.com
}

Received: 25 October 2018

Accepted: 20 July 2019

\begin{abstract}
This research is to reveal The Protagonist's Suffering Depicted in Chris Gardner's Autobiography: The Pursuit of Happyness. The research adopts qualitative research method in its analysis. The main theory used in this research stated that suffering can be defined as a state of severe distress associated with events that threaten the intactness of the person. It can occur in relation to any aspect of the person in the realm of his social role, his group identification, his relation with self or body, or in relation to family or relation with a personal or transcendental source of meaning. The experience of being hurted since he was child makes the protagonist grows with wisdom and maturity. He considers that all the suffering he faces is a part of life that he must pass. It is also found that the protagonist passes his suffering patiently and thinking positively without blaming other people or the situation which make him suffer.
\end{abstract}

Keywords: protagonist, suffering, attitude, wisdom, maturity

\section{Introduction}

There are many stories of single mothers struggling to raise their kids against incredible odds, and with little help. Still, it is rarely to hear the story of single fathers going through the same struggle. Christopher Gardner is one of those fathers.

The Pursuit of Happyness is about Christopher Gardner, a man who went through many trials and tribulations to be successful. He was born to a mother who experienced abuse. He did not know who his father was; his mother's abusive boyfriend threw his face in every chance he got. The experience of having no father allowed Chris to be a good father to his son at all circumstances.

Chris Gardner's life story is so impressive, although he has never gone to college, and after a period of being homeless, he became a wildly successful stockbroker and wrote his memoir, The Pursuit of Happyness in 2006.The Pursuit of Happyness tracks this happy, rags-to-riches story, including his unhappy childhood and his adult progression through a few different careers.

The misspelled "Happyness" of the book's title comes from when Gardner was looking for daycare for his son so Gardner could pursue his career. He rejected one facility because it misspelled "Happiness" in its name, but gained insight into what happiness meant to him personally when he explained the literal meaning of the word to his curious son.

The memoir, both a New York Times and Washington Post \#1 bestseller, has been translated into over 40 languages and was the inspiration for the acclaimed movie, The 
Pursuit of Happyness. Gardner is the main actor in this movie. He acts as Will Smith, who received Golden Globe, Screen Actors Guild and Academy Award nominations for his performance.

Gardner has also been honored by the NAACP Image Awards with awards for both the book and the movie versions of The pursuit of Happyness. They are Los Angeles Commission on Assaults Against Women's (LACAAW) 2006 Humanitarian Award, The Continental Africa Chamber of Commerce's 2006 Friends of Africa Award, The Glaucoma Foundation's Kitty Carlisle Hart Lifetime Achievement Award, and by The Securities Industry and Financial Markets Association (SIFMA) among others.

The reseacher is interested to choose this novel as the source of the subject matter in her thesis because this novel has some good messages and moral lessons. The best message in this novel is for not giving up quickly when things get difficult because success can be gained by hard working. So it is okay to fail in the beginning. Beside that, this book is a good book for teenagers who want to know where they want to go in their life. This book also can be a great motivation for some people who have not really been through anything in their life, and they will realize how fortunate they are compared to Chris Gardner who must work hard to change his life become a better one.

Precisely, the researcher chooses the Protagonist's Suffering as the topic to be analyzed. This book tells about how a homeless single father becomes a successful stockbroker. To get his success, Gardner must experience many forms of suffering, whether it is mental suffering or physical suffering. From that point, she realizes that suffering is the most often shown in the book.

After reading the novel, The Pursuit of Happyness by Chris Gardner, the researcher found that the protagonist has many forms of suffering. From that facts, the writer found that there are four forms of suffering which are faced by the protagonist, such as; Childhood Stress, Racial Discrimination, Divorce, and Homelessness. These four points are the subject matter of this thesis. Furthermore, she also would like to analyse the way how the protagonist passes his suffering.

For this research, the writer concerns with the forms of suffering that exist in the novel. Even though, there are many of interesting theme or topic in the novel, but it is important to limit the subject matter in a research. The researcher only focuses on the topic which deal with the protagonist's suffering as described previously. In other words, other topics that are not related to this research will not be discussed.

By making a research on the subject matter presented above, hopefully, this research provides enough information for anyone to know about suffering and to face it. Generally, to reach the dream, every person must experience many kinds of suffering. This research gives a great motivation about dream and how to reach that, of course with hard working and great efforts. In addition, this study gives contributions especially for others writers who want to do a research which is relevant with the topic of this research.

\section{Literature Review}

A protagonist is the main character in a story, novel, drama, or other literary work, the character that the readers or audiences emphasizes with (Fowler, 1987: 32). Wiley (2010) says that "Protagonist is a person who plays a leading or active part". Other expert tells that if protagonist in ancient drama is the first actor to enggage in dialogue with the chorus, in later dramas playing the main character and some minor character as well (Harcourt, 2013: 187) 
Based on the understandings of the protagonist above, a protagonist can be defined as the first actor in one literary work. Protagonist is a character who pushes the action forward. Since the protagonist is the central character of a story, she or he is the one who has to work as an emotional heart of the story. Some stories weave many characters into an esemble story but even in such stories there is one character that is more important in the story than the rest. Moreover, a protagonist should not always a man, but a woman has the same opportunity to be protagonist in one story. It tells how important the protagonist in the literary work such as novel, short story, play and others. Furthermore, protagonist is usually seen as a good person or hero and heroine. She or he is usually round and dynamic. A protagonist sometimes described with bad personalities. As in some of William Shakespeare's works such as Hamlet, Macbeth, King Lear and many more.

Suffering represents a dimension of personal distress that goes far beyond physical, or evenemotional, pain. There is no consensus on a single, precise, and comprehensive definition of human suffering (Wilkinson, 2005: 97). Cassel (2004: 43) said that suffering can be defined as a state of severe distress associated with events that threaten the intactness of the person. It can occur in relation to any aspecst of the person in the realm of his social role, his group identification, his relation to self or body, or in relation to family or relation to a personal or transcendental source of meaning. Suffering never affects only one part of a person but it affects the whole being; i.e. physical, emotional, mental, spiritual and social aspects. Nobody has ever expected having a suffering. A person can suffer enormously at the distress of another, especially a loved one. That's why, suffering is a unique personal experience and can only be defined by the person who suffers (Oreopoulos, 2005: 17). Suffering is the experience of distress or disharmony caused by the loss, or threatened loss, of what we most cherish. Suffering involves dissolution, alienation, loss of personal identity, and/or a sense of meaninglessness. It results from the stripping away of beliefs and symbols by which we construct a meaningful narrative of human life in general and our own lives in particular. Suffering is often compounded by a sense of threatened or lost dignity.

Stress is often described as a feeling of being overloaded, wound up tight, tense and worried (The Australian Psychological Society, 2012). Stress can mean different things to different people. For some persons, it can threaten totake over their lives while for others, once they are aware of its causes and effects, stress can add excitement and challenge to their lives. Meanwhile, childhood according to Macmillan Dictionary is the age span ranging from birth to adolescence. Thus, childhood strees can be defined as a pressure that occur to a child under the age of 14.

United Nations (2001) defines the term discrimination as "any distinction, exclusion, restriction or preference based on race, colour, descent, or national or ethnic origin which has the purpose or effect of nullifying or impairing the recognition, enjoyment or exercise, on an equal footing, of human rights and fundamental freedoms in the political, economic, social,cultural or any other field of public life".

Race is a social construct that artificially divides people into distinct groups based on characteristics such as physical appearance (particularly skin color), ancestral heritage, cultural affiliation, cultural history, ethnic classification, and the social, economic, and political needs of a society at a given period of time. Racial categories subsume ethnic groups. Racial discrimination is one type of discrimination that often exists in the society. The belief that some races of people are better than the others makes discrimination exist in the society. Racism or racial discrimination usually happens by discriminating people 
by their race or their skin color. Furthermore, racial discrimination refers to the separation of people through a process of social division into categories not necessarily related to races for purposes of differential treatment.

In a marriage life, no married couple wants to end their relationship with divorce. Divorce (or the dissolution of marriage) is the termination of a marital union, the canceling and or reorganizing of the legal duties and responsibilities of marriage, thus dissolving the bonds of matrimony between a married couple under the rule of law of the particular country and or state.

Some experts also give definition about divorce. Milne (1986: 54) defines divorce as a legal process that begins at the point of separation. Another definition from Kaslow, (1979-1980) he defines divorce as a legal process to a more integrated view of divorce as a multi-dimensional process involving both legal and psychological matters. Divorce can be a stressful experience: affecting finances, living arrangements, household jobs, schedules, parenting and the outcomes of children of the marriage as they face each stage of development from childhood to adulthood. If the family includes children, they may be deeply affected. Some of the effects assosiated with divorce include academic, behavioral, and psychological problems. Although this may not always be true, studies suggest that children from divorce families are more likely to exhibit such behavioral issues than those from non-divorced families.

As a common thought, homelessness is the condition of people without a regular dwelling. People who are homeless are most often unable to acquire and maintain regular, safe, secure and adequate housing, or lack "fixed, regular, and adequate night-time residence. Homelessness is a lack of permanent housing resulting from extreme poverty, or, in the case of unaccompanied people, the lack of a safe and stable living environment. Homelessness and poverty are inextricably linked. Poor people are frequently unable to pay for housing, food, childcare, health care, and education. Difficult choices must be made when limited resources cover only some of these necessities. Often it is housing, which absorbs a high proportion of income that must be dropped. Being poor means being an illness, an accident, or a paycheck away from living on the streets. The combination of the high cost of living, low-wage jobs, and high unemployment rates only exacerbate these problems and force them to choose between food, housing, and other expenses.

\section{Research Method}

This study adopts qualitative method by Sandelowski (2000:337) as the outlined. He explains that qualitative method is suitable when detailed descriptions of phenomena an a focus on the presentation of participants' dialogue with the researcher are desired. Qualitative research is a research that relies on qualitative data to investigate the research problem. In as much as the research problems should drive the method of qualitative research (Speziale and Carpenter, 2007:80), a qualitative method matches my research problems because this study is discussed about the protagonist suffering as the phenomena in someone's life.

\section{Discussion}

The focus of this study is the analysis of the protagonist's suffering in Chris Gardner's novel The Pursuit of Happyness. The forms of suffering that has been experienced by the protagonist are Childhood Stress, Racial Discrimination, Divorce and Homelessness. Basically, Suffering is the experience of distress or disharmony caused by 
the loss of what we most cherish. Suffering involves dissolution, alienation, loss of personal identity, or a sense of meaninglessness.

\subsection{Childhood Stress}

Intensive and prolonged stress can lead to a variety of short- and long-term negative effects mentally and physically. It can disrupt early brain development and compromise functioning of the nervous and immune systems. Childhood stress can lead to health and mental problems later in life including alcoholism, depression, uncommunicative, introvert, eating disorders, heart disease, and other chronic diseases.

The protagonist named Gardner in this novel has experienced suffering since he was a child. Young Gardner lived with his sister at a foster house or sometimes at their family houses. Gardner who was still three years old had no idea where his parents were. It can be seen in the following quotation.

What I did know by the age of three or four was that Ophelia was my older sister and best friend, and also that we were treated with kindness by Mr. and Mrs. Robinson, the adults whose house we lived in. what I didn't know was that the Robinsons' house was a foster home, or what that meant. Our situation-where our real parents were and why we didn't live with them, or why we sometimes did live with uncles and aunts and cousins-was as mysterious as the situations of the other foster children living at the Robinsons'. (Gardner, 2006: 9)

The quotation proves that lately, the protagonist knew that his mother was in jail, as a prisoner. His mother was sent away to the jail unfairly by his cruel stepfather.

No one ever laid out the sequence of events that led my mother being prosecuted and imprisoned for alleged welfare fraud. It started out with an anonymous tip, apparently, that somehow she was a danger to society because she was earning money at a job-to feed and care for her two children (Ophelia and me) and a third on the way (my sister Sharon)-and was receiving assistance at the same time. That anonymous tip had come from Freddie, a man willing to do or say anything to have her locked up for three years because she had committed the crime of trying to leave his sorry ass. (Gardner, 2006:

From the two quotations above, it can be seen that the protagonist faces a difficult situation. It must be hard for a child to live without a mother, even though it is just for several months or years. Gratefully, he is surrounded by kind people like his sister and his uncle.

After his mother was released from jail, he asked her some curious questions about his father. Still, his mother refused to answer the questions. His mother seemed discomfortable to talk about his husband who was Gardner's father. We can see his curious expression from the quotation below.

Later on in my adolescence there was one occasion when I pressed her about just who my father was and why wasn't in my life. Moms gave me once of her searing looks, the kind that got me to be quiet real fast.

"But..." I tried to protest.

She shook her head no, unwilling to open up.

"Why?" 
"Well, because the past is the past," Moms said firmly. Seeing my frustration, she sighed but still insisted, "Ain't nothing you can do about it.' She put a stop to my questions, wistfully remarking, "Things happen." And that was all there was to it.

(Gardner, 2006: 13)

It is normal that Gardner feels curious to know some information about his father. It must be painful for a child who never knows who his father is. Living without a father makes young Chris feel distressed. This situation also makes him get bullied by his cruel stepfather. His hard life is seen in the following quotation.

My hunch was confirmed when launched the line he loved to throw at me every chance he got, which killed me every time he said it, stirring up the sediment of anger and resentment that would later erupt. Unprovoked, out of nowhere, he turned to me that first time I can recall seeing him and proclaimed in no uncertain terms, eyes blazing and voice blasting, "I ain't your goddamn daddy!" (Gardner, 2006: 17)

Normally, other children will cry or angry when they are treated like that. Gardner may be different from other children of the same age. We can see how patient he is confronting the situation. He even does not give any reaction for any ill-treatment he receives. Probably it is because he is a sensitive and introvert boy. He always keeps all of the pains he gets in his heart without telling anyone. His stepfather also hurts his feelings by mocking his physical appearance.

Freddie had just made his point one too many times, on top of his incessant commentary about the size of my ears.

Even when I was standing nearby, whenever anybody asked about where I was, he answered with a roar, "I don't know where that bigeared motherfucker is." (Gardner, 2006: 20)

In such a young age, Gardner cannot do anything to avenge the bad treatment. Even if he wants to resist his stepfather, he is not strong enough to repulse his stepfather because his stepfather must be ten times as strong as he. Forcefully, he chooses not to do anything and keeps silent.

Gardner's stepfather often releases his anger to him and his family without any reason. He often beats him and sometimes it makes him almost killed as seen in the following quotation.

All I know is the clubhouse is being chopped down with me in it, Terry has split. Not only does Freddie not give a damn that I'm inside, he seems uninterested in the fact that splintering wood has slashed into one of my legs, which is now bleeding a small river onto our structureturned-woodpile as I shriek from pain. Freddie is impervious, like a human buzz saw, demonically possessed with turning our annoying noisy project and me into mulch. (Gardner, 2006: 29)

But by the time we returned home, he was back to his old self, beating Moms, me and my sisters, going for his shotgun, waking us all up in the middle of the night to get out of his "goddamn house". (Gardner, 2006: 62)

The quotations above describe how rude his stepfather treats him. It is a nightmare for Gardner to have a rude and cruel stepfather like him. He always craves for the loves and cares from a father. He also yearns figure of a father that he never met in his life. 
However, the reality is different from what he has imagined. His stepfather often berates, bullies, beats and yells at him.

\subsection{Racial Discrimination}

Racial discrimination is a situation when an individual is subjected to unequal treatment or violence against people because of their race. The belief that some races of people are better than the others makes discrimination exist in the society. Racism or racial disrimination usually happens by discriminating people by their race or their skin color.

Gardner who was born as an African American and has black skin, often gets some forms of discrimination, not only in his childhood, but also in his adulthood. It can be seen in a situation when his mother was beaten by his stepfather. He was looking for a help from someone he met. However, he was refused harshly and called with a racial calling.

"Mister, look," I say, dashing toward him, out of breath, "can you please give me a dime? I gotta call the police, 'cause my stepfather's about to beat up my mother."

This cat, he doesn't blink an eye, saying only, "You can't hustle me, nigger."

Now I want to kill this motherfucker in addition to Freddie. (Gardner, 2006: 31)

Discrimination also happened when he wanted to be close with a girl in his school. The girl showed her racial behaviour toward him because of his physical appearance.

For years I had hated Smokey Robinson for being the epitome of the kind of guy that ever girl I knew wanted. Slender, light-skinned, greeneyed, with his wavy "good" hair and lilting voice, he had no idea how he ruined life for tall, muscular, dark-skinned, "nappy"-haired baritone guys like me. Even to this day, I swear, if he came in the room I'd have to challenge him to a damn duel for pain and suffering-including the time a girl I liked turned her nose up and told me, "You just a big black ugmo." (Gardner, 2006: 53)

He also got another racial treatment when he joined army as a navy student. One day at a gas station, the owner who was a white person chased him away and told him that she would not sell gas to him because he was a black man.

The local gas station didn't roll out the red carpet. In fact, no sooner had we pulled in than a skinny-ass old white woman came bearing down us with a double-barreled shotgun, beady eyes blazing death as she announced, "I don't sell gas to niggers! I sold gas to a nigger once, and he tried to burn my place down! So y'all just get out of here right now!" Nothing that overt had ever happened to me. Even pretty Willie was as stunned as I was. (Gardner, 2006: 79)

Another example of racism experienced by the protagonist was when he became a doctor assistant in his navy class (in medical section). He was treated discriminatively by a patient.

That Monday he and his wife marched into the ward, demanding to speak to my superior officer. Both looked at me with disdain, as if to say, Who are you anyway? You're not a doctor and you're black! Though I didn't know what I'd done wrong, I could see that he intended 
to write me up. Finally, he bellowed irately, "You don't know what the hell you're doing! You're dangerous! You shouldn't be here! And for all the good those pills did me, I may as well have been sticking them up my ass!" (Gardner, 2006: 83)

The quotation above shows that Gardner wisely calms the patient down and handles the situation even though the remarks of the patient are painful.

From those above racial treatments, it is revealed that some people treat him rudely just because his physical appearance, which directly tells his identity as a black man. They give bad attitudes toward him even though he does not do anything wrong. They hate him just because of his skin color. Getting some descrimination treatments must be so painful for him. Fortunately, Gardner is wise enough to handle those kinds of racial situation.

\subsection{Divorce}

Divorce is a legal process that begins at the point of separation. Divorce means the failure of the "original family" as a viable entity. The protagonist in this novel experienced divorce and separation as a form of suffering. Gardner made a mistake when he enthusiastically proposed Sherry by a phone call. He never imagined that married life did not always end happily like in a fairy-tale story. We can see his regret about his hasty action from the quotation below.

In a romantic rush, out of the blue, almost just to hear myself say the words, I change whatever subject we're on and ask, "All right, so when we gonna get married?"

Without skipping a beat, Sherry says, "Well, how about June 18?"

(Gardner, 2006: 108)

Ironically, the safe, stable home that I'd wanted since childhood turned out to be too structured, too orderly, too rigid. Later I was able to take the long view and realize that $i$ had gone from one institution, the Navy, to another, marriage, with barely a break in between. At the time, I didn't stop to think about it in those terms, except to realize perhaps that I'd learned the classic lesson: Be careful what you wish for because you might just get it!

(Gardner, 2006: 112)

The above quotations describe that Gardner regrets his rush action. They both are still not ready to face the marriage life. They cannot adapt well with their different personalities, and with reality that they are married now. As a life partner, they must understand each other for their different characters and behaviours.

Gardner feels discomfortable with Sherry and their marriage life. He finds another excitement outside and has an affair with a girl named Jackie.

The real turning point that changes everything in our marriage and our lives comes shortly after that day on the pier when we go out to a party together and my future-in the form of an exotic black goddes named Jackie-sees me checking her out and gives me a look. She is five-ten, statuesque, stacked, wearing a shimmering dress like she's poured into it, just oozing sexual energy.

(Gardner, 2006: 117) 
He should not make a mistake when his marriage is in trouble. However, he makes a fatal mistake by having an affair with Jackie, which makes his marriage completely broken.

He thinks that there is nothing he can do anymore with his marriage so that he chooses to leave Sherry and begins a new life with Jackie.

Sherry soon moved to Oakland, and though we had little contact, it took nine years to be legally divorced, partly because of how paiful it was and partly because of the other drama that was going on.

(Gardner, 2006: 120)

We can see that Gardner actually regrets his decision to leave Sherry. However he also cannot continue their marriage because they still cannot give tolerance for their own different behaviours and personalities. In fact, his second marriage also does not run successfully. He does the same mistake like in his first marriage. He decides hurriedly without thinking it deeply. For the result, he and Jackie often fight for unimportant matters.

Sometimes it's me getting frustrated; sometimes it's her. Jackie runs hot and cold, giving and withholding. She works me; I call her on it. I shut down; she gets defensive. I yell; she punishes. Then it passes, we make love, we move on. Everything's okay again

(Gardner, 2006: 121-122)

One day, he was involved in a strict arguments with Jakcie. He intended to clear their problem, but Jackie refused to talk and went away. He grabbed her wrists and she pulled back, trying to get away. Slowly he released his grip and let her go. Jackie who was unstable fell back into the rosebushes.

Jackie who was really annoyed left the house. After a moment, she was back again with two police officers. She told them that she was beaten by his husband.

The first cop asks how she happened to have scratches on her body, so I point to the roshbushes, explaining how she fell. But the second cop says, "No, sir, she said you beat her, and the State of California treats domestic violence as a serious offense."

(Gardner, 2006: 137)

In a state of total disbelief, he followed the two polices to the prison. However, actually they arrested him because of his unpaid parking ticket. After all of his problems solved and his punishments ended, he returned to his house. But how surprise he was when he saw his house was already empty. In a really tired and shocked condition, he finally realized that Jackie had run away and took their baby with her.

So I tell the truth, minus the part about going to jail, but including pretty much everything that's happened recently; Jackie emptying the house, taking everything, including my car, and especially how she has my son and I don't know where either of them are. (Gardner, 2006: 142)

One day, Jackie came to Gardner's apartment, carrying their son in her arms. She gave their son to Gardner since she was a single parent now, and she was not able to grow his son alone.

Slowly it dawns on me that this isn't a visit but that she's actually leaving him in my care. Though she says little, I know her well enough to realize that this is it and just can't do this anymore. (Gardner, 2006: 150) 
By giving her son to Gardner, it means that she cannot bear all the pressure she has as a single parent, and also she wants to insist that their marriage be ended. Gardner is really happy that he lives together with his son now, but he is also sad because he cannot defend his second marriage.

\subsection{Homelessness}

Homelessness is a lack of permanent housing resulting from extreme poverty, or in the case of unaccompanied youth, the lack of a safe and stable living environment.

The protagonist in this novel began his new job as a stockbroker. He only earned little amount of money as the salary. After he had been released from the prison, his wife and his son left him and vacated the house. This situation made him homeless since he had no place to live in. It was hard for him to find a place to stay just a night because he just had a litte money. Finally, some of his friends in the same office kindly offered a help by inviting him to sleep over.

But that worry raised the ongoing problem that I had nowhere to live other than at Latrell's, at her mother's back house, where I had a room to myself; at Leon Webb's crib, where I crashed on the floor; at the apartment of my childhood friend Garvin's briefly; or occasionally with a couple of different women who didn't mind sharing their beds and their cookin, though I didn't have much to offer in return other than my lasting appreciation. (Gardner, 2006: 144)

We can see that he survives for several days by his friends' helps. Some of them allow him to come over and sleep for a night, others even lend him some money and share their meals and beds with him. It explains how difficult his life is because he just has limited amount of money. He is of course thankful for all forms of helping, but he cannot depend on them any longer. He feels bad begging for a place to stay, meals and even money, so he decides to stay some nights at his office, under his desk.

One evening when at work when I hadn't lined up a place to stay the night, it occured to me that since I was usually one of the last to leave the office, no one would be the wiser if I slept under my desk. After all, I was usually the first one there in the morning too. (Gardner, 2006: 144)

He is so worried and affraid of being caught by other officers; however, nothing he can do. His strong wishes to be succesful make him do anything and throw away the thought that he will be embarrassed if someone sees him sleep at the office and others will know that he is homeless.

However, he could not deny that he was affraid of being punished or even fired by his manager.Therefore he could not stay longer at his office. He finally found a flophouse that served a room and meals for a homeless, with any background such as a person with mental problem, a drug addictions, ciminal and others. Of course this was a hard situation for him since he was not accustomed to it. But he forced himself to accept the situation.

For all intents and purposes, it was a flophouse, though decently kept up, that included three meals a day or whatever I could eat while I was there. This was a different world than any I'd lived before, with people just barely scraping by, some with mental problems or addictions, one stumble away from falling through the crack. Not that I was judging, but I couldn't relate. (Gardner, 2006: 146) 
At that situation, his wife visited him and gave his son to him. Surely it became a dilemma for him. The fact that he was so happy to meet his son again and he could fulfill his promise to become a good father for his children at any circumstances. But it was also a trouble because he had no place to live in, and now he must live together with his son. This was surely a hard situation for him who was homeless and only had a little money.

Whatever is going to happen, two things I know are true. First of all, I have my son back with me and nobody on this world is going to take him away from me again. That's a principle of the universe now. Second-and I already know this to be a fact - we have just become instantly fucking homeless.

(Gardner, 2006: 161)

We all know that being homeless is a thing that no one expects. No one in this world wants to faces the experience of having no place to live. But this must be faced by Gardner. He really wants to give a better life to his child. He believes that one day he can change his life and gives a bright future to his child. Although he himself knows how hurt it is for being homeless. He cannot do anything except finding some safe places to stay for a night with his son. We can see the situation from two quotations bellow:

Your memory changes when you're homeless. Always moving around, changing geography, having no address, no anchors to tie to when events take place. It becomes hard to recall whether something happened a week before or a month before, yesterday or three days ago. (Gardner, 2006: 161)

How did I become instantly homeless, especially now that I was a stockbroker working for Dean Witter? Because children were not allowed at the rooming house. No exceptions. The days of crashing on the couch at my friend's homes were over too. I'd imposed enough when I was in the training program, but to ask to stay for a few nights and add, "Oh, by the way, and my baby too?" - that wasn't going to fly. The ladies I was seeing may have been fond me in the sack but but weren't going to be pleased about me showing up with an inquisitive, active toddler.

(Gardner, 2006: 161)

From the above quotations, we can see how hard it is to find a place to live since he is with his son now. His friends may be gladly allow him to come over at their house when he is alone, but it is hard to find a friend that does not mind allowing him to sleep over for a night and bring along a baby. Furthemore, it is impossible to rent a house or pay for a hotel because he does not have enough money. Forcefully, Gardner takes his son to go to work with him and stays at night at his office, sleeping together under the desk, like he used to do.

To my knowledge, no one there knew that I slept under the desk with Christopher on those nights when I didn't have anywhere to go whether I took him to the babysitter early in the morning, picked him up in the evening, and came back to the office that same nights, or whether he stayed with me in the office that day. What they did know was that I was that I was hungry for success. How literally hungry they didn't imagine. (Gardner, 2006: 154) 
Actually he feels guilty because he cannot provide a proper house for his son. $\mathrm{He}$ is sad because he is forced to involve his son in his difficulties. But he has no choice since he has no money whether to pay for a babysitter to look after his son or to pay for a hotel.

One day when his son began to cry asking for a drink, he said that he would buy him that drink next time because he did not have enough money. But his son did not want to stop crying, he finally gave up and bought him that drink.

"No drink, Christopher." I try to calm him down as he starts to cry.

"We'll have a drink and popcorn next time." This kills me.

The next time we have the same dilemma, I buy him what he wants, unable to say no this time. That's one of the nights that's balmy enough that we sleep, try to sleep, on a grassy corner of Union Square, not far from the same spot where the guy who tried to pick me up once called

San Fransisco "the Paris of the Pacific." (Gardner, 2006: 155)

Since he bought that drink for his son, now he did not have enough money to rent a hotel room. He finally took his son to the Union Square to relax, and to sleep there because the weather was good at that day. But of course he cannot sleep there for nights because the weather cannot be predicted.

One day he met a Reverend named Cecil Williams at Glide Memorial Church in the Tenderloin. Cecil Williams and activists had been feeding the homeless and hungry down in the church basement, at Moe's Kitchen. He followed the line to get some meals for him and his son, he was even given sermons by the kind-hearted Reverend, Cecil Williams. For a while, that sermons settled his heart down.

After several times meeting with Cecil Williams, he encouraged himself to ask an information about where he could get a comfort and cheap place to live.

When I talked to the Reverend, I acknowledged that obviously I wasn't a woman, but I was homeless and I did have a child. Most importantly, I had a job. I just needed someplace to live until I could put together the money to get an apartment

"Fine," he said, not thinking twice. He had been watching me with Christopher. He trusted me. "Go on down there," he reassured me, letting me know who to see and what to say.

(Gardner, 2006: 157)

He finally arrived at the place that Cecil Williams told. It was a small hotel with cheap costs. But there were some requierments for the customers to rent the hotel room, as explained in the following quotation.

The deal was this. No one was admitted into the hotel before 6:00 p.m., and everyone had to be out by 8:00 a.m. No one received a key. No going out once you were in for the night, and no leaving your things in the room because they'd be gone when you returned. When you left the room, you took everything you owned with you. No one was assigned the same room two nights in a row.

(Gardner, 2006: 157)

For the first time, he luckily came on time to the hotel and got a room for him and his son. But it was a hard challenge for Chris to always come on time in order to get a room, since he had to work and look after his son. Unfortunately, he came too late and there was no room left for him. 
The worst of this period takes place in approximately March, right when

I know things are really about to bloom at work, and this one night I

roll in to the front desk at the shelter, where they all know me, and I

hear, "Well, Chris, we're all full, sorry." (Gardner, 2006: 160)

Hopelessly, he walked along with his son leaving the hotel. He only had limited amount of money. He could only use the money to buy food for his son and him. So he thought hard to find a place to stay at least for a night. Suddenly he asked his son a question.

What can I do? Out on the street, I head to the BART station, asking Christopher, "You want to go look at the airplanes at the Oakland airport?" (Gardner, 2006:160)

They went to the BART station and sat for a moment. His son told him that he had to go to the bathroom. He took his son to an individual bathroom at the station which enable him to lock the door from the inside. As soon as they were in, he realized that they did not have to leave immediately. They could rest, wash up, take their time, even sleep, as described in the following quotation.

"We're gonna wait," I explain to Christopher, "'cause it's rush hour right now. So we're gonna wait in here and be quiet, all right?" I make up a game called "Shhh" - I tell him that no matter how loud someone knocks on the door, the objects is not to say a word. No matter what. (Gardner, 2006: 160)

We can see how Gardner calms his son down by saying that they are playing a game. He certainly does not want to involve his son in all this sufferings. That situation is his worst condition ever, where he does not have any money whether to rent a hotel room or to buy a dinner. He feels that he really fell into his deepest failure at that time. He thinks he is a bad father who let his son sleep in an inappropriate place.

With no windows, no ventilation, no natural light, the bathroom was tiled from floor to ceiling and wasn't more than ten-by-five, with one toilet and one small wash basin and a mirror made out of reflective stainless steel. By turning off the light, it was completely dark - dark enough that if I was really tired I could sleep. Christopher had a gift for sleeping everywhere and anywhere. I couldn't bring myself to stay in there for too long, only once or twice staying the night, but for a short period maybe a little more than two weeks, the blessed mercy of BART's public facilities gave me needed shelter during the darkest part of homelessness. (Gardner, 2006: 161)

Even though he knows that he should not take his son to all his problems, he also cannot leave him by giving him back to his mother. He has already promised that he will be a good father for his son since he does not ever feel the love from his father. He is so thankful because Christopher is not a rebelious kid, he never whimperes to his dad. He seems to understand about the hard situation faced by him and his dad.

A question now pulsed maniacally in my brain. Why was I putting myself and my kid through this? Why couldn't I slow down, take longer to get out of the rut, dig into my savings, and put us up back at The Palms? Why did I refuse to break the $\$ 20$ bill that could have bought us a night at the tucker hotel? I followed my gut, which told me that breaking that $\$ 20$ bill meant we might not eat. (Gardner, 2006: 161) 
The reason why he is not able to return to the hotel beacuse he just has $\$ 20$ in his wallet. If he uses that money to rent a room, they will not be able to eat. Gardner's condition is realy tragic. He has a financial problem where he only has limited amount of money and he must use that money wisely. He even must acquisce himself and his son sleep in a bathroom at the station. The only reason he does this is to be able to buy food for his son. It will be sadder to see his son hungry.

\section{Conclusion}

The protagonist named Gardner has experienced suffering since his chilhood, which has affected his adulthood. Instead of growing as an introvert and vengeful person, Gardner becomes a smart, wise and mature person. He chooses to face his suffering calmly and wisely. He positively considers that suffering is the lesson of life that can make him a better person. Because of that, all of the suffering he got makes him maturer and stronger. Besides, it can also be concluded that.

1. Stress in childhood stage can affect the behaviour and personalities of the children in the future.

2. Racial discrimination is prevalent to occur everywhere; it may occur in society, school, campus or working place.

3. An early marriage can destroy a household if the couple do not have enough preparation to build a happy marriage life.

4. Economics factors is one of the main causes of homelessness. The high cost of housing and limited amount of money make the protagonist unable to buy an afforadble house.

5. The protagonist has good attitudes to face the hard times. He is able to pass his suffering because of his wisdom, patience and positivity.

\section{References}

Cassell, E. J. (2004). The nature of suffering and the goals of medicine. New York: Oxford University Press.

Fowler, A. Lastair. (1987). A history of Literature. London: Basil Blackwell. Ltd Gardner, Chris. (2006). The Pursuit of Happynes. New York: Columbia Pictures

Harcourt, Houghton Mifflin. (2013). The American Heritage Dictionary. America: Houghton Mifflin Harcourt Publishing Company

Milne, A. L. (1986). Divorce and Family Mediation: Models, Techniques, and Applications. United States: The Guilford Press

Oreopoulos, Dimitrios G. (2005). Humane Medicine, Volume 5, Number 2.

Sandelowski, M. (2000). Focus on research methods. Whatever happened to qualitative description? Research in Nursing \& Health, 23(4) 334-340.

Speziale, H. S. \& Carpenter, D. R. (2007).Qualitative research in nursing: Advancing the humanistic imperative. (4th ed.) Philadelphia: Lippincott William \& Wilkins.

Wilkinson, I. (2005). Suffering: A sociological introduction . Cambridge: Polity Press.

Biography. http://chrisgardnermedia.com/chris-gardner-biography.html (January 2015).

Divorce. http://en.m.wikipedia.org/wiki/Divorce (February 2015).

Homelessness. http://portal.hud.gov/hudportal/homelessness (June 2015)

Homelessness. http://en.m.wikipedia.org/wiki/Homelessness (February 2015) 